\title{
Historical Evolution and Theoretical Analysis of Chinese Agricultural Product Price Policy
}

\author{
Lin Guangbin \\ Central University of Finance and Economics \\ School of Economics \\ China \\ Zheng Chuan \\ Central University of Finance and Economics \\ School of Economics \\ China
}

\begin{abstract}
This paper reviews the history of Chinese agricultural product theory price policies for more than 4,000 years from origin through development, deepening and reform. Studies have found that a series of original theories about the management of agricultural products were born in China, including the theory of supply and demand, the agricultural economic cycle and the regulation theory of the agricultural products' prices based on the market, the theory of light and heavy, and the support and limit price theory. In addition, Chinese theory and associated agricultural product price policies designed for stability and food supply security were formed as well. Furthermore, the disadvantages of historical agricultural price policy, including theory, objectives, formulation and implementation, were analyzed. Finally, several suggestions were given, including the perfection of laws and regulations system, the establishment of warning, government subsidies, credit, agricultural insurance, futures, storage and customs.
\end{abstract}

Keywords: Agricultural products, Price policy, Chinese theory, Historical evolution

\section{Foreword}

Agricultural price measures may be made by the government in order to adjust to supply and demand (Jiang Nan, 2005). The price level of agricultural products is not only related to the economic income of the farmers and food security, but also affects the living standard of urban residents. Thus, it is an important condition for a smoothly running economy. Therefore, in recent years, China has attached great importance to its agricultural price policy and has introduced a series of measures to reform prices. As a country with an ancient history that also relies heavily on agriculture, China is continuing theoretical and practical exploration in its price policies for agricultural products. In this paper, the history of Chinese theory about agriculture price policies is summarized and evaluated in light of current market conditions.

\section{The evolution of Chinese agricultural price policy}

Price policy of agricultural products of China has experienced periods of origin, development, deepening and reform. Each period has shown significant changes yet a certain regularity and continuity because of the ruling party's governing philosophy, main social contradictions and stage of the development of productive forces.

\subsection{The origin period: The Pre-Qin period (21st Century B.C. - 2nd Century B.C.)}

During this period, the traditional agricultural production of China was formed. The early money and the trade of agricultural products developed quickly, and agricultural product price management policy first appeared.

The first record of agricultural product price management in China appeared in Zhou Li. The officials engaged in the management of agricultural prices were Si Jia, Si Shi and Jia Shi. They decided the market price of grain, which resulted in stabilized prices. (Yu Yaohua, 1988). The price policy of agricultural products originated because of the need to store the grain to guard against famine. In order to resist natural disasters such as drought and flood, the rulers of the Xia Dynasty believed in social relief and price adjustment through grain preparedness (Shi Ji, Zhou Li, Li Ji). It took three years to cultivate and accumulate enough food for one year. 
Having a grain storage system for price stability and protect against famine is similar to the modern stabilization fund that the government uses today for both micro and macro policies. Later in this period, according to Shi Ji, Dayu had explored statistics within the jurisdiction of the land, property and population and created a tax system for nine states. The implementation of a tax system according to land and time for people throughout the area aligns with the modern taxation principles of equality, convenience, elasticity and justice. During the Xia, Shang and Zhou Dynasties, the rulers followed the "tithe" principle of taxation and taxes were not to be excessive. In the late Warring States, Qin Xiaogong appointed Shang Yang to implement reform and a policy of restraining commerce. Through a system of tax breaks, people were permitted to expand agricultural production. There was a guaranteed supply of agricultural products, which stabilized prices. Then Guan Zhong (719 B.C. - 645 B.C.) came to be regarded as a great political leader, economist and strategist in ancient China. His thoughts were influential to later generations. His light and heavy theory referred to ancient agricultural product price regulation and control of classical thought. According to the law of supply and demand, price changes in China would impact supply and demand for cereals and other grains. When grain prices were too low, the state adopted takeover measures. When the prices became too high, the country would sell grain until the price returned to normal levels. This resulted in stability (Guangbin Lin, 2015) Thus, grain was stored when prices were lower in order to be sold when the price increased. At the same time, the light and heavy theory related the grain price and the quantity of money, which included the simple idea of the quantity theory of money, which states that when there is more money in an economy, prices will rise In addition, Guan Zhong analyzed international food prices from the perspective of international trade.

Soon after, Fan Li (536 B.C. - 448 B.C.) came to prominence as a politician, economist and businessperson. He put forward the agricultural cycle theory and Pingtiao theory. The agricultural cycle theory proposed 3-year, 6year and 12-year agricultural cycles related to the planet Jupiter and observed seasonal circulation patterns in an agricultural economy (Hu Jichuang, 1998). Pingtiao theory refers to the elastic range of grain price changes. The prices are stable between 30 and 80 coins per dan, which is beneficial to agriculture and commerce, and can ensure an adequate supply of food. This is equivalent to the modern theory of "cheap grain hurts farmers" and "expensive grain hurts people." However, the policy section of modern microeconomics seldom explains who created this theory or which country fostered this belief. Prices of agricultural products are still supported and limited based on Fan Li's economic theories (Lin Guangbin, 2015).

Next, a reformer and financial expert, Li Kui (445 B.C. - 395 B.C.), proposed fertility of education as a theoretical framework and created agricultural economic reproduction theory. This theory developed and expanded on production and ensured supply, price supports, policy restrictions and tax elasticity for the granary system. This led from simple reproduction to expanded reproduction within China's agricultural economy. Li Kui analyzed the serious consequences of food prices that were too high or too low. Accordingly, he designed and put forward specific proposals, and Pingdi implementation made Country Wei strong. The harvest was divided into " abundant," "medium" and "light" while famine was divided into " extreme," "medium" and "light" which would be relieved by the three kinds of harvests respectively (Han).

The policies of Xu Xing (372 B.C. - 289B.C.), a famous agronomist and thinker, was prominent in the Warring States period. He thought that prices of agricultural products should be strictly controlled (Mencius). He believed that the price of agricultural products should be kept stable. This view already contained the idea of market structure although the agricultural products market was an incomplete competitive market. Nevertheless, Xu Xing believed that if the market for agricultural products was homogeneous and the competition was sufficient, the price would be the same. This is known as the "Uniform rice theory."

However, Mencius (B.C. 372 - B.C. 289) criticized the food price management of Xu (Mencius) Because the quality of agricultural products was uneven, there were many changes in prices. Mencius believed that if a price did not change, it would cause confusion in the market. He made an extension for the idea of market structure -that the agricultural market is an imperfect competitive market because the agricultural products are different and thus the prices cannot be the same. Scholars in the Pre-Qin period divided the market into two categories, which served as the early market structure theory for the world.

\subsection{The development period: Qin Dynasty to the Five Dynasties (2nd Century B.C. - 10th Century A.D.)}

In this period, the Pingzhun method, Changping granary and other policy measures appeared, based on the light and heavy theory and the Ping Tiao theory. Sang Hongyang (152-80 B.C.), Chancellor of the Exchequer, developed the Pingzhun method. He proposed the stability in the prices of agricultural products. 
This was different from previous price adjustments due to the use of a large amount of material and economic power to sell and buy (Shi Ji). This method was used in conjunction with the Junshu method, which achieved the effect of stabilizing prices. However, this method resulted in the local executive deviation and other defects, so it was opposed by scholars at the subsequently Yantie conference. Later in this period, Geng Shouchang, a mathematician, and Dasinong, a minister of agriculture, created the Changping granary system (Wang Wensu, 2015). Geng Shouchang proposed the establishment of a grain warehouse in order to stabilize the prices of agricultural products. When the price of food was too low, the government would buy food at a price higher than the market. When food prices were too high, the government would sell it at a price below the market price. Geng Shouchang changed the Pingdi ideology of the pre-Qin period into the Changping system, which was easier to operate, and made important contributions to agricultural products price management theory. The Changping granary resulted in a stabilization fund and retained the importance of grain price policy.

In order to increase food supply and reduce the cost of the frontier, leaders of the Han Dynasty began to implement the Tuntian system. The system provided the rulers with sufficient rations, reduced the cost of grain transport, provided a tax for the rulers, played the role of indirect regulation and controlled prices of agricultural products. Then Mingtun came to the Cao Wei period and Shangtun came to the Ming Dynasty for sufficient agricultural product supply and stable prices. Liu Yan (718-780 A.D.) in the Tang Dynasty implemented the Changping method to manage agricultural prices (New Tang). He advocated settings officials, reported local information of agricultural production regularly, and collected grain at a higher price in harvest. In addition, he attached great importance to changes in food prices in all parts of the information network to monitor changes. Liu Yan's monitoring was very constructive -- similar to the current listed transaction of agricultural products on the spot market -- and could solve the problem of market information asymmetry.

Later, Bai Juyi (772 - 846 A.D.) advocated "currency quantity theory" and emphasized the use of regulating the quantity of money and prices for agricultural products (Bai Juyi). He believed that food prices that were too high or too low were the result of a heavy or light money supply. When the amount of money in circulation was low, the price of agricultural products was low and could damage agricultural production. He believed in "easy money" to increase the circulation of money in the market to buy food and raise the price of agricultural products. In the Tang Dynasty a dense storage network was formed. Center Taicang supplied for royal cereals, capital officers, etc. Zhengcang in county received tax, paid the salaries of official. Army cang included Junzhen Cang and Junshu Cang. Changpin granary was aim to stabilize prices and played a great role in stabilization of prices. Soon after, Yang Yan (727-781 A.D.) worked with financial experts to formulate the "two tax law" which means to tax according to capital. This became an important part of tax theory (Old Tang). Land, industry and wealth were taxed according capital. This was considered a breakthrough in Chinese economic thought and institutional history.

\subsection{The deepening period: Song Dynasty to the Qing Dynasty (10th Century A.D. - 20th Century A.D.)}

During this period, the population in China grew quickly. Consequently, the demand for agricultural resources increased significantly, the supply of agricultural products expanded, and the use of price control policy gradually deepened. "New Changping," also known as "Qingmiao," was one of the reform measures from Wang Anshi (1021 -1086 A.D.) of the Song Dynasty (The history of the Song Dynasty). This method changed the old Changpingchang system. It was based on the flexibly to convert grain storage to cash which was then loaned to farmers and artisans to limit usurious exploitation and increase the fiscal revenue for the government. A thousand years ago, China produced an official "agricultural loans" philosophy, which was a pioneering work in the history of price regulation. In the short term, it increased fiscal income and stabilized the prices of agricultural products.

After many years, the Di and Tiao method of the Song Dynasty had been developed in detail. Numerous people including He, Jie, Ji, Biao, Jun, Bo, Dui and Kuo helped develop the Di and Tiao method which played a major role in price stability in the Song Dynasty. The storage system of the Ming Dynasty also was very detailed. The storage was built in capital, straight provincial, county, border area. The Ming Dynasty lasted more than 200 years and the prices of agricultural products did not fluctuated during this time due to price management measures.

Then Zhang Juzheng (1525-1582 A.D.), Prime Minister of the Ming Dynasty, advocated a tax policy known as "one whip." This meant that the servitude system was gradually abolished and personal relationships were weakened significantly in order to promote the development of monetary rent. This led to an increased food supply, stabilized prices for agricultural products and the development of the economy during this time. 
The development of the storage system reached its peak during the Qing Dynasty (1644 A.D. - 1912 A.D.) This was attributed to the reign of Emperor Qianlong at the beginning of the Qing Dynasty who developed an extensive and efficient warehousing system. In the Qianlong period before (1644-1736 A.D.), the prices of agricultural products were stable although there were price fluctuations because of natural disasters. Yongzheng of the Qing Dynasty implemented the "tan ding ru mu" policy. This meant that all unpaid farmers were incorporated into the land. This system completely abolished the Ding tax implemented during the Han Dynasty. Feudal society in China underwent a significant tax system reform. This played an important role in promoting agricultural production and stabilizing agricultural product prices.

\subsection{The reform period: The Republic of China - the "new" China (since the beginning of the 20th century)}

Old China experienced a period of turbulence (1912-1949) that included the northern warlords, the Kuomintang, the Second Sino-Japanese War and the war of liberation. Before the Second Sino-Japanese War, domestic prices remained relatively stable, and the grain price fluctuation range was smooth (Kong Min, 1988). During this period, agricultural price policies were not taken seriously. After the Second Sino-Japanese War, China experience inflation and the prices of agricultural products greatly increased. In Shanghai, for example (Shanghai grain records), rice prices rose six million times and wheat prices rose 13.65 million times during the eight-year war; the price of rice rose 4.7 billion times between 1937 and 1949. To stabilize food prices, the Kuomintang government established food policy management, strengthened grain production and reverted land taxes to the state. It played a tiny role, but unrewarded own to the spamming of legal tender and gold yuan and serious inflation.

A number of grain price support policies also were implemented in revolutionary base areas and liberated areas. Party organizations and the Soviet government had taken a variety of measures, such as the establishment of the Food Swap Bureau and various forms of cooperatives. Also, private businesses were protected and encouraged. During the war of resistance against Japan, the border area implemented the Pingdi system whereby public stores acquired grain from farmers at a price $2 \%$ higher than that of the market in autumn; it was then sold in the spring. This regulated the food supply and stabilized the price of the grain. Before the reform and opening up of China (1949-1978), there was a period of free buying and selling dominated by the state (1949 - 1952). In the early period after the founding of "new" China, the new regime faced a very tight grain supply, which led to sharp fluctuations in the market prices. Thus, the government wanted to stabilize prices. Hence, the state decided to unify national material dispatching and implemented purchasing policies that led to state-operated food businesses. Beginning in 1953, the country entered a new era of large-scale socialist economic construction. In order to solve the food problem properly, China had to implement a large-scale food-purchasing plan the price of the acquisition and the supply price were unified by central law or with the approval of the central government. Overall, prices agricultural production was very low to support development of industry in this period and then there was an obvious price scissors between industrial and agricultural products.

Since the reform and opening up (1978-present), the Chinese economy has gone from an agricultural society to an industrial society. The reform of agricultural price policies changed from "industry nurtures agriculture and rural areas support cities" to "industry nurtures agriculture and cities support rural areas." In addition, there has been an effort to promote agricultural development and increase the income of farmers. Between 1979 and 1984, the nation kept unified purchase and sales records and gradually ceded the control of part of agricultural products, adjusted prices of agricultural products and opened up trade fairs. Before 1978, regulated prices were 5.6\% of the total amount of agricultural products market. This increased to $18.1 \%$ in 1984. In 1979, the State Council gradually increased the purchase price of grain, cooking oil, pigs and 18 other important agricultural products with an average price increase of $24.8 \%$. Thus, this greatly stimulated faster agricultural development and effectively promoted the agricultural products price formation of the market process. In 1984, there was an oversupply of Chinese total grain output. In 1985, China began the reform of the grain purchase and sale system and changed the unified purchase price of 30 years to a food contract ordering system. Contract food orders varied for wheat, rice, corn and soybean from a centralized area. The subscription price of the implementation was the price ratio of "inverted 3-7"-- 30\% productions according to the original purchase price, $70 \%$ productions over it, which allowed the farmers to sell freely.

Market forces were used to reform the price of agricultural products. During the period of 1992 to 1996, China established the protection price system and sales price policy and grain risk fund system. 
In addition, the Agricultural Development Bank of China was established in 1994 to end managed grain purchase funds. In 1995, the "rice bag" governor responsibility system was used to solve the food balance of the area and country. Moreover, the reform of policy and commercial business was carried out separately in food sector. Between 1997 and 2003, three policies were started: wide buy, arranging valence sales and the acquisition of funds in a closed operation. One reform was accelerating the reform of the state-owned grain enterprise: In order to separate the duties of central and local governments and perfect the grain prices, protective prices were implemented on open purchase policies in the market. With the deepening of the reform, China's grain circulation system had to give up the status of state-owned grain enterprises to establish a modern method of government intervention in the market. From 2000 to 2006, with the rapid development of industry, the concept of industry nurturing agriculture had gradually become the core of the agricultural policy. The central government began implementing an agricultural tax relief policy. In 2000, the Jiangxi Province pilot cancelled the agricultural tax. In 2003, the central government taxes and fees were reformed and expanded nationwide. The average peasant burden was reduced more than $30 \%$. In 2004, China cancelled agricultural specialty taxes except for the tobacco tax, and exempted the agricultural taxes of eight provinces. In 2005, 28 provinces were exempt from the agricultural tax. In 2006, China abolished agricultural taxes. This marked a fundamental change in the state, which had an historic impact on the supply and prices of agricultural products.

Since 2004, China has liberalized its grain purchases and market sales, implemented minimum grain purchase prices, temporarily stored grain and provided direct subsidies to farmers. In 2004, the nation fully liberalized its grain purchasing market and established direct subsidies to grain farmers. This included the implementation of large-scale grain growing subsidies, seed subsidies, farm machinery purchase subsidies and production subsidies. Since 2005, according to the relationship between market prices and the minimum purchase price, China has determined the minimum purchase price plan on a variety of grains. In 2008, the nation increased the minimum purchase price level for wheat and rice and expanded the implementation scope of the minimum purchase price of rice. Then in 2009 and 2010, the state continued to raise the minimum grain purchase prices. Overall, along with social transformation and development, Chinese agricultural product price policies also have continuously changed. Especially since the reform and opening up, in order to improve the income of the peasants and the stability of the consumer market, China has phased out unified purchases and sales, abolished agricultural taxes, implemented price support policies and gradually moved toward the path of an agricultural products market. As a result, prices of agricultural products also have increased gradually.

\section{Chinese theory and project of agricultural products price management}

In combing through the historical evolution of agricultural product price management in China, there seems to be evidence that the nation has formed a series of original theories, including the theory of supply and demand, agricultural economic cycles and the regulation of the market prices of agricultural products, support prices and limited price theory. In addition, Chinese theory combined with a series of agricultural product price supports and a stable food supply has advanced with the times.

\subsection{The originality of theory}

History shows that the theory and practice of Chinese agricultural product price management has played an important role in national governance, and many ideas were original in economic theory. Guan Zhong's theory of "heavy and light" of Guan Zhong, for example, is essentially the theory of supply and demand. That is, the price is affected by the supply; the price will be expensive when a product is scarce and cheap when a product is abundant. In particular, Guan $\mathrm{Zi}$ used food as a strategic tool to stabilize the national economy. Later, Fan Li, Xu Xing and Mencius claimed that the prices of agricultural products were influenced by both supply and demand. This shows that the ancient people of China for the price fluctuation of agricultural products knew supply and demand theory, as a kind of common economic law. Besides, Fan Li puts forward the earliest agricultural cycle and agricultural products price regulation theory. Periodic changes in agricultural production determine the cyclical fluctuations in the prices of agricultural products. Therefore, Fan Li proposed a solution: An effective national response for the intervention of food market prices can prevent the price from fluctuating, which can lead to the development of agriculture, industry and commerce. Fan Li advocated regulating supply and demand measures to control the prices of agricultural products based on spontaneous fluctuations in the market prices, rather than directly controlling the food through administrative means. The open market of food regulation, namely according to the market price, supplemented by government price adjustment policy guidance, provides an historical reminder of how agricultural product price reform began. 
Furthermore, Guan $\mathrm{Zi}$ was concerned with the relationship between the price of agricultural products and the quantity of money. He believed that money and grain prices are opposites. Thus, he believed that the state should increase the quantity of money in the society by spending money on the acquisition of grain to raise its price. Bai Juyi posited a more systematic theory known as the currency quantity theory. Finally, according to the social and economic problems, the theory and knowledge were demonstrated by creating an illustration of the institutional mechanisms that have comprised the integrated system of Chinese economic theory (figure 1).

Figure 1: Policy-making path of Chinese ancient agricultural product price

\begin{tabular}{|c|c|c|}
\hline $\begin{array}{l}\text { Social and economic } \\
\text { problem }\end{array}$ & $\begin{array}{l}\text { Policy theoretical } \\
\text { basis }\end{array}$ & Policy formulation \\
\hline $\begin{array}{l}\text { Abnormal price } \\
\text { fluctuation }\end{array}$ & $\begin{array}{c}\text { Theory of supply and } \\
\text { demand }\end{array}$ & $\begin{array}{l}\text { Stabilization fund: Light and heavy, } \\
\text { Pingtiao/di method, Pingzhun method, } \\
\text { Changping method }\end{array}$ \\
\hline & & $\begin{array}{l}\text { Tuntian method: Juntun, Mintun, } \\
\text { Shangtun }\end{array}$ \\
\hline $\begin{array}{l}\text { High prices hurt people; } \\
\text { low prices hurt farmers }\end{array}$ & $\begin{array}{l}\text { Economic circle } \\
\text { theory }\end{array}$ & \\
\hline Social instability & $\begin{array}{l}\text { Quantity theory of } \\
\text { money }\end{array}$ & $\begin{array}{l}\text { Agricultural tax: tithes, two tax, one } \\
\text { whip, "tan ding ru mu" policy }\end{array}$ \\
\hline \multicolumn{2}{|r|}{ Feedback } & \\
\hline
\end{tabular}

\subsection{The completeness of the price management system}

According to the level of price system, the price system of agricultural products includes four levels: commodity market price, capital market price, rent market price and monopoly market price. In China, the prices of agricultural products in the history are reflected in different degrees within these four levels, and it takes a series of measures to regulate the price (Table 1).

Table 1: The price system and policy system of agricultural products in China

\begin{tabular}{|c|c|c|c|c|c|c|}
\hline \multirow[t]{2}{*}{ level } & \multicolumn{2}{|l|}{ Price form } & \multicolumn{4}{|c|}{ Policy system in various stages } \\
\hline & General price & $\begin{array}{l}\text { Agricultural } \\
\text { product price }\end{array}$ & Origin period & $\begin{array}{l}\text { Development } \\
\text { period }\end{array}$ & $\begin{array}{l}\text { Deepening } \\
\text { period }\end{array}$ & Reform period \\
\hline \multirow{4}{*}{$\begin{array}{l}\text { First level: } \\
\text { commodity } \\
\text { price }\end{array}$} & \multirow{4}{*}{$\begin{array}{l}\text { Living } \\
\text { consumer } \\
\text { goods price }\end{array}$} & \multirow{4}{*}{$\begin{array}{l}\text { Grain spot; } \\
\text { market retail } \\
\text { price }\end{array}$} & Heavy \&ight; & \multirow{4}{*}{$\begin{array}{l}\text { Pingzhun; } \\
\text { Chang Ping; } \\
\text { Juntun; } \\
\text { Mintun }\end{array}$} & \multirow{4}{*}{$\begin{array}{l}\text { Chang } \\
\text { Ping; } \\
\text { Shangtun }\end{array}$} & \multirow{3}{*}{$\begin{array}{l}\text { Lowest purchase } \\
\text { price; temporary } \\
\text { storage box; yellow } \\
\text { box policy; }\end{array}$} \\
\hline & & & \multirow[t]{3}{*}{ Pingtiao (di) } & & & \\
\hline & & & & & & \\
\hline & & & & & & $\begin{array}{l}\text { land reclamation } \\
\text { policy; early warning }\end{array}$ \\
\hline $\begin{array}{l}\text { Second } \\
\text { level: } \\
\text { capital price }\end{array}$ & $\begin{array}{l}\text { Interest rate; } \\
\text { exchange } \\
\text { rate; } \\
\text { dividends }\end{array}$ & $\begin{array}{l}\text { Products } \\
\text { futures prices; } \\
\text { agricultural } \\
\text { loans }\end{array}$ & & & $\begin{array}{l}\text { Agricultural } \\
\text { loans } \\
\text { (Qingmiao) }\end{array}$ & Futures; loans \\
\hline \multirow{2}{*}{$\begin{array}{l}\text { Third } \\
\text { level: } \\
\text { rent price }\end{array}$} & \multirow{2}{*}{$\begin{array}{l}\text { Tax rate } \\
\text { (political } \\
\text { rent); rent } \\
\text { (economic } \\
\text { rent) }\end{array}$} & $\begin{array}{l}\text { Agricultural } \\
\text { taxes and fees; }\end{array}$ & \multirow[t]{2}{*}{ Tithe; acre tax } & $\begin{array}{l}\text { Zu yong diao } \\
\text { system; }\end{array}$ & \multirow{2}{*}{$\begin{array}{l}\text { One whip; } \\
\text { "tan ding ru } \\
m u \text { " policy }\end{array}$} & \multirow{2}{*}{$\begin{array}{l}\text { Abolition of } \\
\text { agricultural tax; } \\
\text { agricultural subsidies }\end{array}$} \\
\hline & & land rent & & $\begin{array}{l}\text { two tax law; } \\
\text { rent tax }\end{array}$ & & \\
\hline \multirow{2}{*}{$\begin{array}{l}\text { Fourth level: } \\
\text { monopoly } \\
\text { price }\end{array}$} & $\begin{array}{l}\text { Low price of } \\
\text { monopoly; }\end{array}$ & \multirow{2}{*}{$\begin{array}{l}\text { Low price of } \\
\text { buy high price } \\
\text { of sell }\end{array}$} & \multirow{2}{*}{$\begin{array}{l}\text { Monopoly of } \\
\text { the high price } \\
\text { of the Guan } \mathrm{Zi} \text {; } \\
\text { tariff }\end{array}$} & \multirow{2}{*}{$\begin{array}{l}\text { Restricting } \\
\text { price and } \\
\text { export }\end{array}$} & \multirow{2}{*}{$\begin{array}{l}\text { Restricting } \\
\text { price and } \\
\text { export }\end{array}$} & $\begin{array}{l}\text { Import tariff policy; } \\
\text { export subsidies; }\end{array}$ \\
\hline & $\begin{array}{l}\text { high price of } \\
\text { monopoly }\end{array}$ & & & & & tax refund policy \\
\hline
\end{tabular}




\subsection{The continuity and marginal improvement of the price management policy}

The price policy of agricultural products has had a rather obvious continuity in every period of China. Each dynasty, based on the theory and practice of the previous dynasties, learned from the experiences and lessons of the past. Marginal improvements and innovations were made to the various policies, as they were adapted to current conditions. The concept of a stabilization fund can be traced back to the Xia Dynasty, followed by Guan Zhong's heavy and light theory. Similarly, the national food prices were the result of convergent regulation. Ping tiao (di) developed theory and implemented the national grain reserves system, and the effects were remarkable. Next, the implementation of the Pingzhun method of price regulation was used in the Han Dynasty. This was then combined with Changping storage systems in later dynasties - namely the Tang, Song, Ming and Qing -- the Changping storage was the main policy for stabilizing prices and continues to play an important role. This approached peaked in the Qianlong period of Qing Dynasty. Subsequently the Changping method declined due to corruption, war and other reasons, and the prices of agricultural products continued to rise. In the period of the Republic of China, the national unification area and border used storage and Pingtiao to stabilize food prices. After the founding of "new" China, especially after the reform and opening up to the outside world, the state established relatively complete agricultural products price support policies, stable food storage systems and a policy bank to guarantee funds for purchasing grain and storage to manage and regulate food prices.

\subsection{The relationship between the price management policy and the vicissitudes of dynasties}

The Changping method and other agricultural products price policies were the central government's policy, and the rises and falls of those reflects the vicissitudes of feudal state power. In the Tang Dynasty, for example, at the beginning of the second emperor, Li Shimin's reign, the nation had established a series of policies to "rehabilitate," the Changping method to stabilize prices and famine. As a result, grain prices were stable from 3 to 20 qian/bucket for many years. The state showed "Zhenguan prosperity." However, a hundred years of "rebellion" caused the Datang destiny to fade, and the policy of benefiting was deserted. Then, the economic reformer vigorously promoted national interventionist policies, and implemented Changping to manage agricultural prices and reversed the economic decline. A short-lived, but flourishing, age of the Tang Dynasty provided no return, and the Changping method of the late Tang Dynasty eventually fell apart. The Changping method also has been used for reference by the United States in its agricultural policy. In fact, it has laid the foundation of contemporary agricultural legislation in the U.S. and guaranteed it is a strong, competitive power in the world. The exploration of ancient China in the agricultural price policy also made an important contribution to the world economy and the study of economics.

\section{The malpractice of Chinese agricultural price management policy and program}

\subsection{Policy theory}

Agricultural product price policy is a government behavior. In the early stages of the market, it can play a role in stabilizing prices. However, with the development of a commodity economy, the government's excessive interference with the market may be a "failure of government." This policy can strengthen the leading role of a country and lead it to substitute resources, create a centralized overweight, run contrary to the rules of a market economy, damage the normal operation and influence of the market and disturb an efficiency advantage in setting food resources, It can eventually adversely affect the food supply and may bring greater food security risks even in the long term. In addition, there is a certain lag of the policy from the discovery of the problem to the development and implementation of the policy. The ancient transport infrastructure was not developed, so the government's price adjustment may be slower than the market, which will affect the efficiency of policy.

\subsection{Policy objectives}

In the early stage of agricultural product price policy, the aim of the policy was to increase China's income. The heavy and light theory harbored a strong profit motive. The grain reserve regulation was an effective way to increase revenue by manipulating food prices by national power and administrative orders and artificially manufacturing an imbalance of food supply and demand and grain prices fluctuation. The purpose was to earn much more money f or a feudal country to solve its financial difficulties. This would not only cause food price fluctuations, but also turn the policy function into an alienation of commercial operations. Thus, it was difficult to achieve the intended purpose and sometimes was counterproductive. 


\subsection{Policy formulations}

In ancient times, there were many problems in the policy formulation. First, the central authority was too concentrated; there were too many management links. For example, in the Qing Dynasty required layers of reports about Changpin. However, the Changping method had a multi-level division of labor, which made it difficult to stabilize prices. Second, the location was a problem. In the plan and establishment period, the Changpin granary was situated within the city walls. But because of cost, the granary was not easy to village, so the policy tended to stagnate in the city and not in the countryside. Third, storage was a problem. Due to a lack of scientific knowledge and technology, the natural loss in the storage process was difficult to avoid. This provided officials a reasonable excuse to seize grain for purchasing and storage, which left loopholes in the system design.

\subsection{The implementation of the system}

Although a strict management system and punitive measures were established, there still were many problems produced in policy-specific implementation of local officials. For example, the Pingzhun method resulted in a local executive deviation and other defects. The Changping granary uncovered problems in the procurement cycle and misappropriations of disaster relief funds. In the implementation process of a "New Changping," officials acted recklessly cheated poor households, and the interest rate doubled. In contemporary society, the current system also has many regulatory loopholes. For example, the national grain reserve has had deficits and other problems have occurred.

\section{The recommendations of Chinese current agricultural price policy}

\subsection{Handling the relationship between state and market properly}

The relationship between the state and the market, in essence, is the relationship between the government, enterprises, families and individuals. The excessive interference of agricultural products prices is easy to produce market disorder, control delay and a series of problems, so China needs to respectfully the laws of the market when policies are formulated. The relationship between the state and the market should be divided. In the formation of agricultural products and the trade of agricultural products, when market supply and demand are stable, it should be attributed to spontaneous market forces. When a serious imbalance in market supply and demand appears, and in the international trade market, the state government should play a leading role by taking guidance of low or high prices of agricultural products based on historical experience, temporary storage, price regulation, tariff barriers and other measures.

\subsection{System design}

System construction is the key to institutional innovation, which is the prerequisite for the smooth implementation of agricultural policies. Today's advanced transportation, communication and technology tools have overcome some of the defects of the system inherent in the ancient times, and now it is urgent to reform the system design. Nevertheless, the central grain reserves system still exists and prices are high because of governmental control. Therefore, China can simplify policy management and optimize institutional innovation to prevent officials and management from profiting from them. This is especially important about discounts. In addition, China should establish agricultural product price regulation in the field of production and circulation and deal with the relationships between government, enterprise, family and individuals.

\subsection{The implementation of the supervision system}

Today, the case of agricultural price policy is in the implementation process. It also is mired in an endless stream of corruption. Today, the supervision and management of the implementation of the policy needs to be strengthened to increase the fight against corruption. This is an important guarantee to ensure the smooth implementation of the system. For instance, concerning the grain policy, China should strengthen the enforcement of laws and regulations and the relevant provisions, and ban corruption, malpractice for personal gain and increase the supervision and inspection of all kinds of illegal behavior. On the other hand, China needs to regularly carry out the clearing and inventory work throughout the nation, determine the food inventory and provide the government with accurate reports on a regular basis to ensure national food stocks are in tune and national food security. In summary, Chinese agricultural products price management practice and exploration of 4,000 years provides a valuable theoretical and practical experience for current agricultural product price reform. China needs to have some theoretical inheritance and innovation. Especially, it needs to give priority to laws and regulations policy systems, establish a price regulation system for agricultural products, and handle government subsidies, credit, insurance, futures, purchasing and storage of agricultural products and customs, etc. 
China also needs to strengthen the supervision and inspection of the implementation of policies, cracking down on illegal behavior and ensuring the security of the national economy and social stability.

\section{References}

Jiang Nan, Fang Tianwang, Zhang Zheng (2005). The necessity of agricultural price policy implementation and its evolution. Agricultural economy, 9, 62-63.

Wan Jianzhong translation (1988). Zhou Li. Dalian: Dalian Press, 50-105, 165-208.

Yu Yaohua (1988). An overview of China's ancient history of price. Price monthly, 8, 45-46.

Si Maqian(2008). Han Zhaoqi translation. Shi Ji. Beijing: Zhonghua Book Company, 24-30, 648, 2144, 25282553.

Wang Wenjin (2001). Translation of Li Ji. Beijing: Zhonghua Book Company, 170.

Lin Guangbin (2015). China is one of founding countries of classical political economy. China review of political economy, 9 (5), 68-105.

Wang Wensu, Sun Yugang, Hong Gang (2015). Ten Tong financial literature comment. Beijing: China Social Science Press, 139-147, 353-355, 489-498.

Hu Jichuang (2015). The history of Chinese economic thought (First). Shanghai: Shanghai University of Finance and Economics Press, 180.

Ban Gu (2007), Han. Beijing: Zhonghua Book Company, 159.

Fang Yong translation (2010). Mencius. Beijing: Zhonghua Book Company, 97-98.

Lu Simian (1971). New Tang. Taiwan: Commercial Press of Taiwan, 207-216.

Bai Juyi (1979). Bai Juyi. Beijing: Zhonghua Book Company, 1311-1312.

Liu Xu (1975). Old Tang. Beijing: Zhonghua Book Company, 3418-3425.

Alutu (1977). The history of the Song Dynasty. Beijing: Zhonghua Book Company, 10541-10550.

Kong Min (1988). Nankai economic index compilation. Beijing: Social Science Press of China, 59.

Shanghai Grain Bureau (1995). Shanghai grain records. Shanghai: Shanghai Academy of Social Sciences Press, 228-231. 